\title{
EDUPOLY - AZ SSC SZEKTOR NÉPSZERÜSÍTÉSÉNEK LEHETŐSÉGEI
}

\section{EDUPOLY - OPPORTUNITIES TO PROMOTE THE SSC SECTOR}

\author{
MUCSI RÉKA \\ EDUTUS Egyetemen \\ gazdálkodási és menedzsment szakon végzett hallgató
}

DOI 10.47273/AP.2020.21.83-99

\begin{abstract}
ABSZTRAKT
A mü bemutatja az Employer branding folyamatát és a Gamification, mint az SSC szektor népszerüsítésének másik lehetőséget. Fő mondanivalója azonban az Edutus Egyetem oktatási folyamatait elősegítő ,játék” kitalálása, annak felhasználása és lehetséges tovább fejlesztése.
\end{abstract}

\begin{abstract}
The work presents the process of Employer branding and Gamification as another opportunity to promote the SSC sector. However, its main message is to invent, use and possibly further develop a "game" that promotes the educational processes of the Edutus University.
\end{abstract}

\section{Bevezetés}

A kutatásom témája a rengeteg lehetőséget magába foglaló, de sokak számára mégis ismeretlen SSC (Shared Service Centre) szektorhoz kötődik, azon belül is employer branding adta gyakorlati lehetőségeket taglalja. A szektor müködése számtalan megválaszolandó kérdést rejt magában, mint például, hogy meddig fejlődhet az SSC szektor és mi a fejlődésének az alapja? A szolgáltatók Magyarországi jelenléte, mennyire befolyásolja az ország aktuális gazdasági helyzetét? A hatalmas munkaerőhiány hogyan érinti a cégeket? Mit tesz az ágazat, hogy a mai 
generációt elérje és megtartsa, és mindezt milyen módszerekkel? A kutatás központi kérdése, pedig az, hogy hogyan lehet népszerüsíteni a szektort, valamint hogyan segíthet ebben az employer branding és a gamification. E célok elérését segíti elő az általam kidolgozott Edupoly nevezetü társasjáték, ami a cikkben részletesen bemutatásra kerül. A játék igyekszik minél hamarabb felkelteni a fiatalabb generáció érdeklődését és egy érdekes tanulságos játékon keresztül mutatja be nekik az SSC szektort és annak előnyeit, kihívásait.

\section{Employer baranding, mint a szektor népszerüsítésének egyik lehetôsége}

Az employer branding magyarul „munkáltatói márkaépítés” egy nagyon felkapott témává vált az elmúlt években. Sok helyen tapasztalható/olvasható a különböző szektorokat érintő munkaerőhiány, ennek súlyossága, ami indokolttá teszi, hogy foglalkozzunk vele, hisz a munkaerő megtartása számos esetben egyet jelent a cég müködőképességével. Egyes felső vezetők szerint több cégnek is stratégiai beruházásokról kell lemondaniuk ezen ok miatt. Munkáltatói arculata - mérettől függetlenül - minden cégnek van. Azonban ennek a hatékony felépítése nem egyszerü feladat. Lényege, a hitelesség, vagyis, hogy a cégek kommunikációja valódi tartalmakat tükrözzen és ennek kapcsán megfelelően cselekedjenek. A cég egyediségét hangsúlyozza, ami versenyelőnyt biztosít más vállalatokkal szemben. Vagyis egyfajta keveréke a hagyományos HR és marketing területeknek. Az utóbbi időben nagyon sok minden megváltozott körülöttünk, például a munkaeröpiaci környezet. Korábban a jelöltek álltak sorba azért, hogy bekerülhessenek egy céghez, mára már a cégek állnak sorba a jelöltekért. A cégeknek kell tudatosan felépíteni, rövid, közép, és hosszú távon gondolkoznia, hogy hogyan fogják a megfelelő mennyiségü és minőségü munkaerőt megszerezni, és ami fontosabb meg is tartani, ugyanis ez a vállalatnövekedésnek az egyik akadálya lehet. Rengeteg cég szembesül azzal, hogy próbálja magához vonzani a tehetségeket, azonban mégsem jár sikerrel. Ennek az egyik fó oka az, hogy a célcsoport az online világban van jelen. Tehát az eddigi eljárásokhoz képest ez is egy jelentős változást igényel. Ezen, okok miatt lett ez egy nagyon fontos állomása a HR kérdéskörnek, mely hosszútávon a cég sikerességének egyik kulcsát jelentheti. Elmondható, hogy a szolgáltatói szektor számára a legfontosabb, a munkáltatói márka kiépítése (71\%) ezt követi a telekommunikáció (63\%) végül a pénzügy (58\%) (hvg.hu, 2018) 
1. ábra: Munkáltatói márkapiramis

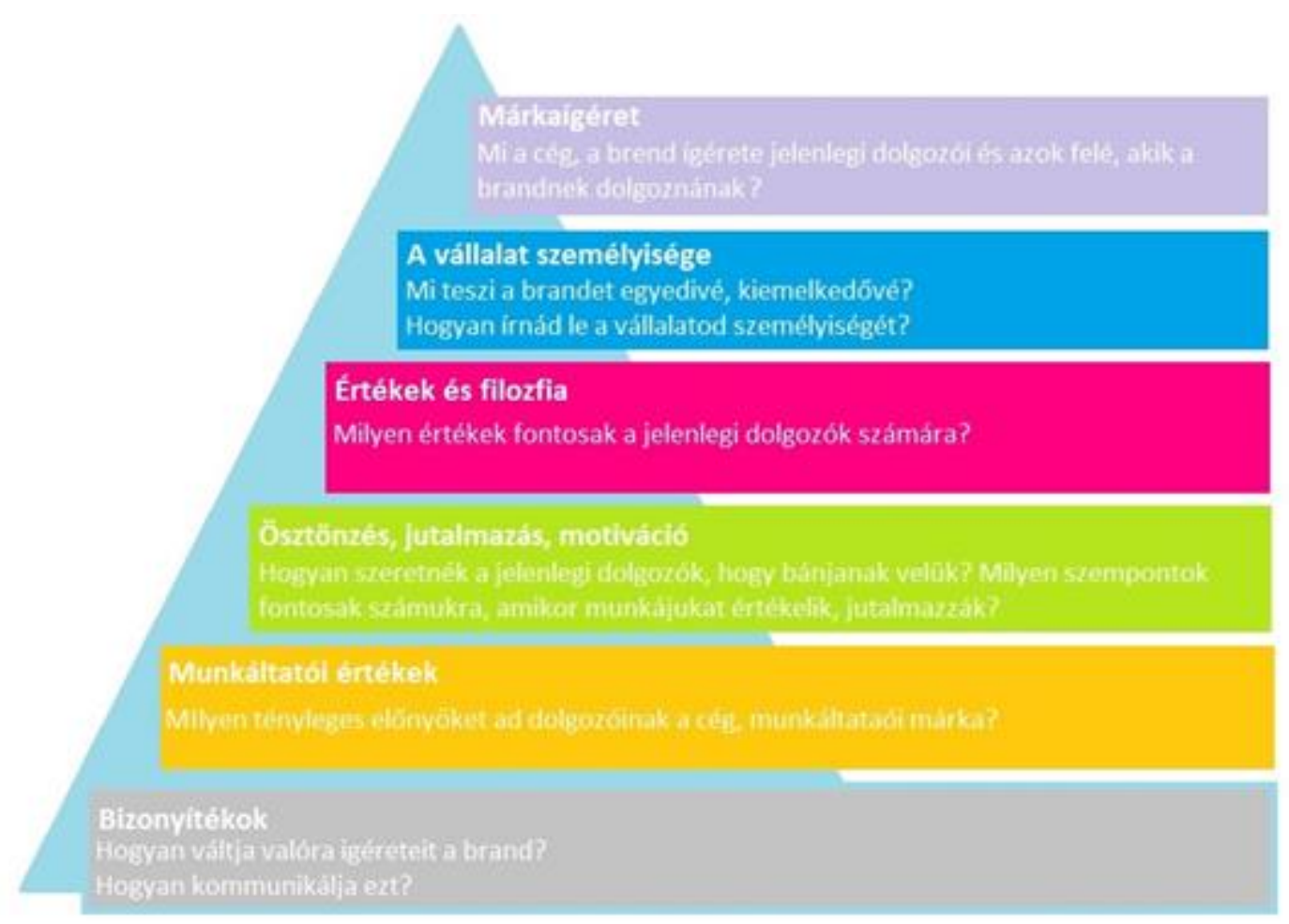

Forrás: Profession.hu, minden az employer brendingröl és a megvalósitás folyamata, 7-18o

Ez az ábra az employer branding tevékenységet, mint egymás alá besorolható folyamatot ábrázolja, melynek tetején a márkaígéret helyezkedik el, ami a cég jelenlegi és jövőbeli ígéreteként jelenik meg. A piramis ábrájához hasonlóan születtek, értékeket és trendeket felsorakoztató elméletek. A különböző kulcsfontosságú kérdéseket a Work Force munkaerőkölcsönző- és közvetítő cég előrejelzései alapján, a (hrpwr, 2019) valamint CsikósNagy Katalin (hrportal, Barna Eszter, 2017) szakmai javaslatai segítségével dolgoztam fel, így ezek a megállapítások a nemzetközi és hazai viszonyok ötvözésével születtek meg.

Mint látható az ábrán, az egész piramist a „Bizonyítékok” tartják. Ide tartoznak mindazok a programok, gyakorlatok, módszerek, amelyek a fenti ígéretekhez hűen megvalósulnak, tehát hitelessé teszik az ígéretet. Több megválaszolandó kérdés tartozik ide, mint például, hogy milyen a munkahelyi légkör? Ösztönzö-e a rendszer, mennyire? Van-e lehetőség rugalmas munkaidőre? „Bizonyítékok” maguk a munkavállalók, akik lojálisak a céghez, akik megvalósult célokat is fel tudnak mutatni, valamint évek óta hüek a céghez. Az információgyüjtés nagyon fontos és elsődleges feladat. Rengeteg adatra van szükség, ahhoz, hogy bármiféle kijelentést, következtetést tegyünk a szektorral vagy akár egy konkrét munkahellyel kapcsolatban. Ilyen például: 
- a munkaerő igény száma,

- az új munkavállaló belépésének száma,

- a kilépő munkavállalók száma.

Az adatokat, célszerü rendszerezni, területenként illetve korosztályon ként vizsgálni, valamint diagrammok segítségével ábrázolni, hogy minél világosabb legyen. Erre épül rá a „munkavállalói értékek”, amik megmutatják, hogy milyen előnyöket nyújt a cég a dolgozói számára. Ide tartozik a szakmai elismertség, a magas fizetés, a kevesebb stressz, illetve, nagyon fontos, hogy a munkavállaló el tudja-e érni az egyéni céljait. Ezt követi az „ösztönzés, jutalmazás, motiváció”, melyet számtalan kutatás vizsgál. Ezek közé tartozik például az elkötelezettség mérés. A cégek nem engedhetik meg maguknak, hogy csak a toborzásra költsenek, a munkaerő megtartása éppen olyan fontos, mint a megszerzése, ha nem fontosabb. A vezetők 84 százaléka kezeli ezt elsődleges fontosságúnak. Erre megoldást nyújthat a mesterséges intelligencia, ami áttörő lesz nem csak a HR-ben, hanem az egész szektorban. Így a HR minden aspektusa mérhető lesz, a toborzástól elkezdve a teljesítménymenedzsmenten át egészen a munkavállalók viselkedéséig bezárólag. (hvg.hu, 2018). Azonban nem csak az elkötelezettséget kell mérni, hanem a hangulatot is, például egy névtelen teszt kitöltésével, megkérdezhetjük a dolgozókat, hogy miért szeretnek nálunk dolgozni. Mindenképp legyünk tisztába azoknak az elkötelezettségével, akik az új munkavállalókat fogadják, mert kihat rájuk és hamar tovább állhatnak. Eredményeként pedig elmondható, hogy rendkívül fontos a munkavállalók egyedi igényei szerinti jutalmazás, ösztönzés. Ha tudjuk, kit mivel lehet motiválni és azt a gyakorlatban is alkalmazzuk, egy pozitívan befolyásolja a munkáltatói márkát. A következő szintje a piramisnak az „Értékek és filozófia”. Ez a szint a munkavállalók értékrendjét vizsgálja. A vállalatnak érdemes megtudnia az alábbi tényezőket. Milyen értékeket vall a munkavállaló? Közel áll-e a cég által képviselt értékekhez? Az egy csapatban dolgozók értékrendje mennyiben egyeztethetö össze? A visszajelzés is fontos! Nyugodtan kérdezzünk rá csoportvezetőknél, dolgozóknál is, milyen kihívásaik vannak, miben látják a változás okát, ők, hogyan kezelnék azt, Van-e szükségük támogatásra, és ha van milyenre? Mi sem egyszerübb, mint egy kérdést feltenni, a másiknak. Hisz mind egyediek vagyunk, más kép gondolkozunk, valamiben jobbak valamiben rosszabbak vagyunk. Ezek a visszajelzések csak megkönnyítik a vezető munkáját, ahogy a feltörekvőben lévő intelligens technológia használata is. Ezeket a tényezőket a „vállalat személyisége” követi. Itt a külső érintetteken van a lényeg, méghozzá, hogy ők hogyan látják a vállalatot. Gondolok itt arra, hogy a belsős személy miképp írja le a vállalatot, azáltal a külsösben milyen kép alakul ki arról. Így nem csak, hogy hiteles marad a vállalat, hanem a potenciális dolgozókat is bevonzza, akik egyszerủen be tudnak illeszkedni, 
hiszen egy számukra szimpatikus céghez érkeznek. A csúcson a „márkaígéret” helyezkedik el. Ez a cég által hirdetett ígéretekből áll, amit a dolgozók számára tettettek. Minden alatta lévő felsorolt érték nagyon fontos, mert ezekből épül fel lépésről lépésre a márkaígéret. Akkor lesz teljes, ha ezek a feltételek egytől egyik teljesülnek. Ha bármelyik hiányzik, akkor már nem úgy fog müködik a rendszer, ahogy az el lett tervezve. A munkáltatói márkaépítés már nem újkeletü dolog, annak kreatív módon való megközelítése, viszont igen. Sok cég marketing ügynökséghez fordul, hogy kreatív kampányokat indítsanak valamely közösségi média platformon. Akár influencerek használatával is lehet frissíteni a kommunikációt, amelyben a hosszabb-rövidebb videóknak sokkal hangsúlyosabb szerepet kellene szánni. A hangsúly a kreativitáson van, ami a jelek szerint 2019-ben már igazán fontossá vált. Az elmúlt években a szellemi munkavállalók magatartása is változást mutatott. Jellemző, hogy a munkavállaló először referenciát kér az általa kiválasztott cégekről, az alkalmazottaktól és azután döntenek arról, „arcukat” adják-e a céghez. Ez visszautal a 2-es pontra, amiben a hangulatmérés fontosságát hangsúlyoztam. Nagyon fontos tehát, hogy amit a cég a munkavállalóinak ígér, valódi tartalommal rendelkezzen, igazodjon a belső folyamatokhoz, mert különben hatalmas csalódáshoz és fluktuációhoz vezethet. Ezek azok a tényezők, amik alapján kijelenthetjük, hogy az employer branding-el foglalkozni kell.

A kutatásaim alapján kijelenthető, hogy a marketing kampányok helyett a munkáltatói márka és az élmény alapú employer branding stratégia lehetővé teszi a cég számára, hogy belülröl, biztos alapokra építkezzen. Ami a toborzásban is segíthet, hisz a munkatársak a saját megélt tapasztalataikat, értékeiket adhatják el a leendő alkalmazottaknak a történeteiken keresztül, ami valószínüleg sokkal rokonszenvesebb a mostani generáció számára, mint a száraz előadások, felsorakoztatott adatok, eredmények, amit amúgy sem értenek, meg, ha nem részese a cég életének. A jövő nemzedék igényeire éppen ezért érdemes nagy hangsúlyt fektetni, mert kulcsfontosságú szerepet töltenek be a szektor jelenlegi és jövőbeli életében.

\section{Gamification, mint a szektor népszerüsítésének másik lehetősége}

Nincs kifejezetten ráillő magyar szó, egyelőre a ,játékosítás” szóval szokták helyettesíteni. A kifejezést 2002-ben egy brit játékfejlesztő - Nick Pelling használta először. Sebastian Deterding és köre: O’Hara, Sicart, Dixon és Nacke, 2011 májusában számolt be arról, hogy a gamification kifejezés korábban ,informális gyüjtőfogalomként” volt használatban, amely alatt többnyire a videójáték-elemek játékon kívüli környezetben való használatát értették. (ludus.hu, 2015) A fogalom megértéséhez elsősorban különbséget kell tenni két játéktípus között. Az angolban 
használt „play” és „game” között. A play, a spontán önmagáért való játékot jelenti, amely elsősorban a gyermeki játékhoz köthető. Ezzel szemben a game, már szabályokkal együtt egy mindenki számára ismert cél érdekében számszerüsíthető játékot jelent.

A spontán és a szabályokkal övezett játék is örömet okoz, nem csak a gyerekeknek, de a felnőtteknek is. Általában azért játszanak, mert kellemesnek találják. Egy műveletet addig végeznek, amíg az újszerüen hat, amíg kihívást biztosít számukra. A játék során rengeteget lehet tanulni, megismerkednek az ismeretlennel, érdekes tapasztalatokat szereznek, ezáltal nem az eredmény a fontos, hanem maga a cselekvés, ami egyre összetettebbé válik. Ennek az ideje többnyire meghatározatlan, nincs kimondott lezáró jelenete, csak egy kimondott célja, ami akár belső feszültségből is indulhat, nem kizárt, hogy egy játék közben az ember felszabadultságot érez, elszakad a valóságtól egy kicsit és ez nyugtató hatással van a játékosra. Egy gyermek komolyan veszi a játékot és szinte azonnal azonosulni tud vele és a benne előforduló szerepekkel, amiben sokszor teljesen szabad választási lehetőséget kap. A játékban keveredik a valóság és a fikció, de a gyermek nem veszti el a realitásérzékét, pontosan tudja, hogy csak játszik. Az utazás a játékok alapeleme. Ez jelképezi az újszerüségnek az ismétlődését, egy újabb kaland kezdetét, amivel egyre közelebb jut a célhoz. (elitmed.hu) A gamification tervezési elemei a ludus-ként kategorizálható játékok elemeit használja. Ez a koncepció egy kételemü mátrixon ábrázolható a legjobban, első két tengelye a ,játékosság”, mellyel szemben a „játékszerüség áll. A másik két tengelyt a „teljességre való törekvés” és a különböző elemekből való építkezés adja. Fontos, hogy Játékelemeket és játékszerü tervezést használ, nem hoz létre konkrét játékot. Így a gamification egyéb rendszereket támogat játék elméletekkel oktatási vagy akár üzleti szférában. A célja, a motiváció és felhasználói élmény fokozása, nem pedig a szórakoztatás. Három játék elemet lehet megkülönböztetni a játéktechnológiát, a játékszerü tervezést, és a játékalapú eljárást. Ezek közül a fogalom csak játéktervezési elemeket használ fel, így nincs digitális technológiához kötve. (ludus.hu, 2015)

Manapság gyakran kell új dolgokat megtanulni és elsajátítani, rendkívül rövid idő alatt, aminek egyik leghatékonyabb módja a játékon keresztül történő tanulás. A ,játékosítás”, egy alternatív értékelési és jutalmazási rendszer is egyben, így a vállalati oktatás és üzleti területeken is kiválóan alkalmazható a gamification. Mindenki volt már olyan helyzetben, hogy egy fontos oktatáson, néhány óra után már nem tudott kellően koncentrálni az előadó száraz stílusa vagy a lecke töménysége miatt. Ilyekor a legjobb, ha a megtanulni kívánt anyagot, legyen az egy tankönyvi lecke, a vállalat müködése vagy akár egy új munkafolyamat, játék formájában is megjelenik. Még nem is beszélünk számítógépes technológiáról sem szoftverekről, elég egy 
ötlet, egy játéktábla, pár figura, dobókocka esetleg pénzérme - és máris egy társasjátékon keresztül jutunk el egy képzelt világba, ahol a vállalati stratégián, új termék bevezetésén gondolkodhatunk. Hasonló elképzelésen alapul az általam kitalált társasjáték is, amely létrejöttét egy egyetemi óra kreatív feladatának köszönhetem.

A tréningeken és csapatépítőkön sem véletlen, hogy a közösséget a játékok során szeretnék közelebb hozni egymáshoz. Játékok során élethosszig tartó kötelékek alakulhatnak ki. Megtapasztalható benne a csapatmunka, mások bátorítása és egyes vezetői képességek is elsajátíthatók. (controllingportal.hu, 2014) A játékban rejlő lehetőségek azonban túlmutatnak egy adott dolog népszerüsítésén. A játékosok örömmel töltenek el órákat benne, amely komoly bevonódást és kognitív figyelmet igényel. Fontos, hogy ezek a kihívások összhangban legyenek a játékos képességeivel, mert a túl alacsony kihívási szint unalomhoz vezet, ellenkező esetben pedig frusztrációhoz. A kitartó gyakorlások eredményeként pedig önmagukat is megismerhetik, számos vonásukat tudatosan fejleszthetik. A játékkal velejár a motiváció kialakulása, a kreatív megoldókészség és a rugalmasság is. Mindemellett, rájönnek, hogy az élet nagyon hasonlít egy szerepjátékhoz, bár egy játékban vissza lehet lépni a mentésben vagy akár elölről kezdeni, az életben nincs ilyen lehetőség, ezért megfontoltabban cselekednek majd, lépésről lépésre a céljaik elérése érdekében. Ennek a felismerése és alkalmazása néhány évvel ezelött indult be, és mára már komoly eredményeket tud felmutatni. A leginnovatívabb cégek 70\%-a már 2015re beépítette a rendszerébe ezt a módszert. Ennek keretében különböző alkalmazásokat és weboldalakat hoztak létre. Az egyik leghíresebb programot a Nike fejlesztette ki, melynek lényege, hogy a futót egy karórába épített GPS kíséri végig, melynek felülete nyomon követi a teljesített távot. Ezáltal lehetőséget teremt a csoport tagjainak, hogy pontokat gyüjtsenek, amit később beválthatnak. Már az Y és föleg a következő $\mathrm{Z}$ generáció tagjait az informatika világában könnyebb elérni. Könnyen boldogulnak a digitális eszközökkel és igényük is van rá. Emiatt készülnek számítógépes és telefonos játékok, amelyek oktatási céllal szerepjátékok müködési elveire épülnek. A The VR csapata is tartott előadást a témakörben. Szerintük az emberek alapvetően szeretnek játszani valamilyen okból kifolyólag, legyen az siker, elismerés, vagy csak magáért a játékért. A virtuális világ, amit az új generáció megszokott a karakterválasztással kezdődik. Azután tapasztalati pontokat gyüjtenek és szintet lépnek, ennek hatására játszva tanulnak dolgokat. 3 fö folyamatra kell odafigyelni egy ilyen játék kidolgozása közben. Szükség van egy mindent átfogó jelenségre, ami értelmet ad az egész folyamatnak. A fejlődés élménye kulcsfontosságú, itt a rövid és hosszú távú célok elérését kell meghatározni, ügyelve a kihívás-küzdelem megfelelő arányára. A harmadik tényező pedig az autonómia, 
melynek lényege, hogy a szereplő a tevékenységeit szabadon választhassa meg. Ezt ismerte fel az SSC szektor, és egy jó RPG játékhoz hűen a fent felsorolt tényezők segítségével alakít ki karrierutakat, ahol folyamatosan skill-eket kell elérniük a feljebb jutás érdekében. (SSC heroes, 2019) Napjainkban egyre többször találkozhatunk automatizált videóinterjúkkal, amik már számos kiemelkedő eredményt tudnak felmutatni. Bár ez a módszer nem állja meg a helyét bármilyen pozíciónál, de arra jó, hogy segítse az előválasztási folyamatokat. A személyes interjú még mindig pótolhatatlan, de legalább már csak a legesélyesebb jelöltekkel kell megtartani. A Benchmarked.games startup kifejezetten olyan játékokat fejleszt ki, amely segítségével egy komplex profil is összeállítható. A mérce az eddigi legjobban bevált dolgozó tulajdonságaihoz van igazítva. (hrpw.hu 2018) Az Egyesült Királyságban (Arctic Shores) kialakítottak a gamification segítségével egy HR stratégiát segítő rendszert. Ez szintén egy játék, amibe pszichometriai elemeket építettek be, amely összetettebb, mint egy kompetencia mérés, mert a tudáson és képességen kívül az attitüdöket és személyes jellemzőket is mérni lehet. (profession.hu 2017)

\section{Edupoly - Az SSC szektort népszerüsítő társasjáték}

Az Edupoly nevezetü társasjáték ötlete az Edutus egyetem egyik tanóráján született meg, ahol azt a feladatot kaptuk, hogy mutassuk be az SSC szektort, azonban tilos volt az eddigi hagyományos PPT-s módszer használata. A feladat megoldásához a kreativitást kellett használni. Ennek keretében született meg az Edupoly nevezetü társasjáték. A szektor bemutatása önmagában nem egy izgalmas téma, ezért olyan megoldások kellenek, amik bevonják az érdeklődőt úgy, hogy érezze ő maga is részese ennek az egésznek. Az Edupoly egy spontán ötletként született, azonban, utólag átgondolva egyértelmüen elmondható, hogy a játék employer branding eszközként felhasználható, valamint egyúttal egy gyakorlati példa a gamificationre is. Ezáltal segíti elő a szektor népszerüsítését.

\subsection{Az Edupoly bemutatása}

A játék a már mindenki számára ismert Monopoly szabályain alapszik. Ebben a sajátos Monopolyban a játék menete az SSC szektorra lett „szabva”. Azért kapta az Edupoly nevet, mert ez által egyrészt utal a játék eredetére a Monopolyra, másrészt pedig az Egyetem nevére, ami lehetővé tette ennek a létrejöttét. Maga a tartalma a föcímben nem szerepel, de alcímként megjelenhet például hasonló formában: „Építs karriert az SSC szektorban!” Az Edupoly célja, hogy a játékosok SSC csoportokat, végső soron egy teljes SSC központot építenek fel, hasonlóan az eredeti játékhoz. 


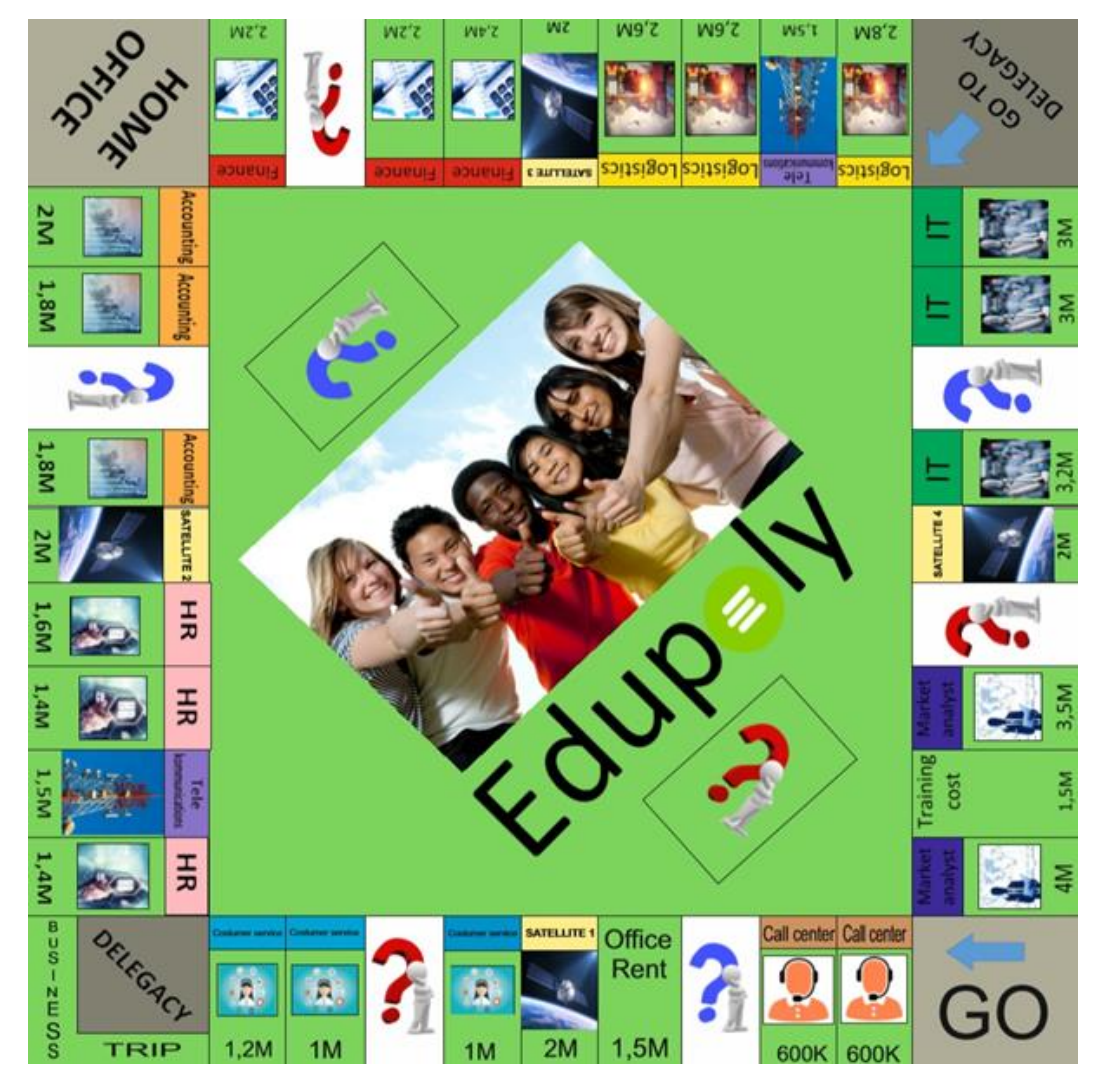

Maga a játék áll egy játéktáblából, figurákból, dobókockákból és a játékosokat segítő kártyákból, amik természetesen előnyöket és hátrányokat is tartalmaznak. A társas angol nyelven készült, mert a szektor fö nyelve is az angol. Az Edupoly tehát, a játék keretein belül ismerteti az SSC szektor legfontosabb jellemzőit. A játékosok megtapasztalhatják, milyen lehet egy SSC-ben dolgozni, milyen kihívásokkal találkozhatnak, milyen karrierutakat járhatnak be az egyes szinteken keresztül. A játékosok GO mezőről indulnak el, és ahogy haladnak körbe, az SSC szektor egy-egy jellegzetes területével találkozhatnak, amelyek egyre nagyobb hozzáadott értéket képviselnek. Ez az egyes területek áraiban is tükröződik. Így a legolcsóbb terület a call center, azt követi az ügyfélszolgálat, az emberi erőforrás menedzsment, utána következik a könyvelés, a pénzügy, a logisztika, az IT és végül a marketingelemzés. Ezeket a területeket lehet megvenni. Miután a játékos megszerezte az egész részleget, például az összes emberi erőforrás területeit a birtokába vette, tehát vezetője lett, ekkor elkezdheti a csapatait kibővíteni és magasabb szintekre lépni. A saját, illetve alkalmazottai fizetését is emelni tudja ekkor. (Mivel, amint egy játékos az ő területére lép a megfelelő összeget fizeti ki, az elvállalt munkáért cserébe.) A szintek a következők: Mivel minden területen más elnevezések vannak, ezért egy egyszerübb megnevezés lett bevezetve a játékosok számára. A legelső szint a „pályakezdő”. Ezt a titulust a játékos az elején megkapja, az életben ez annyit jelent, hogy a sikeres interjú után megkezdheti a munkát a cégen belül, míg a játékban ekkor kezdhet el 
bizonyos területeket megvásárolni. Miután egy egész részleg a játékos birtokába került, feljebb léphet a ranglistán és elkezdheti csapatait bővíteni. Az első csapatbővítéssel megkapja a „Level 1-es" szintet, ami nagyobb csapatot és több bevételt jelent. Tovább haladva értelemszerűen két csapatnál „Level 2”, háromnál a „Level 3” négynél a „Level 4” szintet. Ezután a „Manager” végső szint követi. A Játéktáblán több különleges mező található. Ezek mindegyike kötődik az SSC szektor valamely sajátosságához. Például az információs technikai háttér kiemelkedő szerepére a mühold és távközlési mezők jelenléte utal. Ezek a berendezések a részlegek belső és külső kommunikációját segítik elő, az a játékos, aki rálép, fizet a tulajdonosának a használatáért. A játék felhívja a figyelmet arra is, hogy az SSC-k nagy irodaházakat bérelnek a müködésük érdekében, így ez a játék során egy állandó, előre meghatározott költségként van jelen. A tábla négy sarka a szektor egy-egy fontos állomását jeleníti meg. Ezek között megjelenik a kiküldetés, ezzel jelezve azt, hogy a szektorban van lehetőség kiküldetésre menni ám ez ritka. Jellemzően akkor van jelen, ha valamilyen részleget vagy tevékenységet a központosítás érdekében átszerveznek egy másik országba. Így a játék során sem egyszerü ezt a mezőt elérni. Ez a terület két részre van osztva. Az egyik tehát a már megemlített „Kiküldetés”, ahová akkor kerül egy játékos, ha háromszor egymás után dob két kockával két ugyanolyan számot, (például: két kettest dob, utána két ötöst, harmadjára meg két egyest) ezzel jelezve azt, hogy a kiküldetést ki kell érdemelni - megfelelő munkavégzés és motiváció szükséges hozzá - ilyenkor a játékos kimarad egy körből, mert egy fontos külső feladat elvégzésére hivatott. Az illető akkor térhet vissza a megszokott irodájához, ha ugyan azt a számot dobja ki a két kockával, például két hatost dob, vagy fizet egy megadott összeget, hogy korábban visszatérjen. Ezzel jelezve, hogy a kiküldetések hossza a munka elvégzésével azonos. Tehát a játékosok 3 körig tartózkodhatnak kiküldetésen, ez alatt el kell végezni a feladatukat, ha két azonos számot dob az illető a körében, akkor a feladatot hamarabb teljesítette és haladhat tovább, ha pedig nem tér vissza hamarabb, a harmadik kör után ki kell fizetnie egy bizonyos összeget, ami azt jelzi, hogy a feladatot nem tudta 100\%-osan elvégezni. Említettem, hogy ez a sarok ketté van osztva, amelynek az egyik része az előbb leírt kiküldetés. A másik része pedig az „Üzleti út”. Ez egy rövid egy-két napos tevékenység, az illető bár a munkáját végzi, mégis kizökkenhet a megszokott munkakörnyezetéböl. Jellemzően az SSC-k köreiben elterjedt nem szokványos munkavégzés a „Home Office” is szerepet kap a játék során, utalva arra, hogy ez egy bevett szokás, illetve lehetőség a cégeknél. A játékon belül, ha valaki arra a mezőre lép, nem történik semmi, hisz a munka ugyanúgy el lesz végezve csak a helyszín más. A piros és kék kérdőjelet tartó bábuk egy-egy speciális kártya felhúzására kötelezi a játékosokat. Ezek a kártyák fontos információkat jelenítenek meg a szektorról, ami a játékosokat közvetlen érinti. 
Ezek jutalomkártyák, amelyek a szektorban történő munkavégzés előnyeit hivatottak bemutatni. Részben anyagi ösztönzőkhöz kötődnek, részben a fiatalabb generációk elvárásaira reflektálnak vagy a szektorban alkalmazott valamely juttatási formákhoz kötődnek.

Az anyagi ösztönzőkhöz kötődő kártyák közé tartozik a különböző előléptetésekről szóló kártyalapok. Ezen kártyák hivatása bemutatni, hogy egy SSC-n belül egyszerü vertikálisan és horizontálisan is mozogni. Például:

- A jelenlegi főnököd a munkavégzésed során az ötleteiddel és munkamoráloddal teljesen meg van elégedve, ezért úgy döntött, hogy előléptet, ami „,50.000” Ft pénzjutalommal jár.

- A jelenlegi részlegnél, nem érezted azt, hogy ki tudsz teljesedni, ezért átmentél a logisztikai részlegre. Lépj a hozzád legközelebb eső logisztika területére, és vedd fel az eredményedért járó összeget. „10.000” Ft bónuszban részesülsz.

Az anyagi ösztönző lapok közt vannak olyan kártyák, amelyeknél a fejlesztő vagy újító tevékenységekért cserébe fizetnek jutalékot. Ide tartoznak az új kapcsolatok, technológiai fejlesztések, környezetvédelmi intézkedések, valamint a társadalmi felelősségvállalás. Például:

- Sikerült szerződést kötni egy újabb Felsőoktatási Intézménnyel a te közreműködésed által. Jutalmul „100.000” Ft-ot kapsz.

- Az egyik informatikai alkalmazottad egy új szoftvert fejlesztett ki, ami hatékonyabban müködik, mint az eddig használt. „,60.000” Ft pénzjutalomban részesülsz.

Ide sorolhatók azok a kártyák is, amelyek azért fizetnek jutalmat, mert valaki másra ösztönzően hatottunk, gondolok most az új emberek ajánlás útján történő felvételre - olyanra, aki megfelelő időn belül eredményes teljesítményt nyújt - vagy egy az eddiginél jobb módszer kidolgozása egy bizonyos feladatkörnél.

Az Employer branding elengedhetetlen lett egyes cégek életében, valamint a társasjáték is egy ilyen eszköz. Ezért szerepelnek olyan kártyák, amelyek erre épülnek. Például:

- A céged employer branding díjat nyert, amiben sokat segítettél. Jutalmul „40.000” Ftot kapsz.

- Az éves Budapesti cégek közt megrendezett hangulatmérési versenyében első helyezett lett, a te vizsgálataid segítették elő, hogy a cég tudta, mit szeretnének az alkalmazottak, ami miatt sikerült elnyerni ezt a helyezést, ezért kapsz ,55.000” Ft-ot jutalmul. 
A munkáltatói márkához kapcsolódóan több olyan tevékenység köthető, amely az alkalmazottak megtartása miatt lett kialakítva. Ezek nem feltétlen pénzjutalomként vannak jelen. Például:

- Önként csatlakoztál céged Nyílt napjának megszervezéséhez. Húzz egy szerencsekártyát.

- Vagy a call center csapata jelezte, hogy a kényelmesebb munkakörnyezet érdekében növényeket szeretne az irodába ültetni, amire megkapták az engedélyt. A vásárlásra kapsz „20.000” Ft-ot.

Vannak olyan tevékenységekről szóló kártyák, ami után pénzbefizetési kötelezettség alakul ki. Ilyen például az adófizetés az egyes csapatok után, a rosszul elküldött könyvelési eredmények miatti veszteség. De olyan is előfordulhat, hogy a gyorsan változó igényekre való figyelmetlenség miatt csődbe megy egy részleg és be kellett zárni, ilyenkor a játékban egy a már megszerzett csapatok közül kell visszatenni egyet. Ezen kívül megjelenik a fizetés nélküli szabadságra küldés is, általában valamilyen gyenge munkavégzés, fáradság miatti kiírt pihenés. Ami a játékban egy körből való kimaradással jelenik meg. Ezek a kártyák azért fontosak, mert a leendő alkalmazottaknak a pozitívum mellett a negatívummal is tisztában kell lenniük. A fáradságos és nagy mennyiségü munka, a monotonitás például mind jelen vannak a szektorban.

A fiatalabb generáció elvárásainak való megfelelésnél sok mindent el lehet mondani. Ami, már szerepelt is a különleges mezőknél a „Home Office” lehetősége, vagy a kártyákon a cégen belüli mozgás. A játékosok éppen ezért tapasztalhatnak más mezőkre való átlépésről szóló kártyákat is, szintén valamilyen SSC-re jellemző indoklással. Például:

- A munkafolyamatot, amit eddig végeztél automatizálták, így a fontosabb feladataidra több időd marad, lépj a hozzád legközelebb eső HR terület mezőjére.

Bármikor adódhat olyan alkalom is, hogy a gyermek még kicsi, de a szülőknek dolgoznia kell, a nagyszülők meg nem érnek rá. Lehetőségként a cég kialakíthat ilyen esetekre egy megőrzőt, így az anyuka nyugodtan dolgozhat, szünetében rá is nézhet a gyermekre. Az ilyen típusú kártyák arra szolgálnak, hogy felhívja a figyelmét a játékosoknak arra, hogy egy SSC-ben milyen lehetőségek adottak a számukra. A fiatal generáció folyamatosan tanulni és fejlődni szeretne, ezeket a lehetőségeket pedig a cég fel is kínálja számukra. Például:

- Új területtel szeretnél foglalkozni, amihez egy másik nyelv ismerete szükséges, ezért nyelvi előkészítőre fizet be a cég. (A játékban átléphetsz egy általad választott szabad területre és megvásárolhatod azt, ha nincs szabad terület tedd félre ezt a kártyát.) 
Ezeken kívül a kártyákon szerepelnek még a nyelvi nehézségek. Egyrészt az SSC részéről, akinek meg kell keresnie azt az ember, aki a kívánt nyelvet megfelelően beszélni, itt főleg az egzotikus nyelvekre gondolok. Kártyán ez úgy jelenhet meg, hogy:

- Ebben a körben nem tudod bővíteni a csapataidat, mert nem találsz megfelelő munkaerőt a pozícióhoz.

Másrészt pedig a belső vagy külső kommunikációban okozott nyelvi nehézség, mint félreértés is szerepelhet. Például:

- Félreértetted a külföldi partnered által kiadott munkát, ezért vissza kell fizetned a projektre kapott pénzt. Fizess „40.000” Ft-ot.

A multikulturális közeg is megjelenhet pozitívumként és negatívumként is a kártyákon. Például egy életre szóló barátság megkötése vagy a különböző kultúrák, ételek és emberek megismerésének a lehetősége, ami vagy pénzjutalmat, vagy egy csapattagot jelent a játékon belül. Negatívum pedig, hogy más kultúra más szokásokat hoz maga után, amit nem minden ember tud egyformán elfogadni, vagy egyszerüen csak más értékeket vallanak.

A játék célja, hogy az utoljára játékban maradt illetőé legyen a legtöbb részleg, ezáltal a vállalat vezetőjévé váljon. Kiesni úgy lehet, ha valaki csődbe megy, már nem tud fizetni más játékosoknak, ha nem tudja rendezni tartozását a csapataival és területeivel kell fizetni, és ha ez sem elegendő a tartozások rendezésére, hogy odáig jut, hogy a legelején kapott gyakornoki pozícióját is elveszti, tehát kirúgják a cégtől.

\subsection{Az Edupoly alkalmazási lehetöségei}

Az Edupoly, alkalmazási lehetőségeiről szerettem volna a szektortól is visszajelzést kapni, ezért interjút készítettem egy, a hazai SSC szektorban tevékeny cég HR-esével, Kamrás Elvirával, az AGCO cég HR koordinátorával. Az interjún Elvirát és csapatát arról kérdeztem, hogy tudná-e hasznosítani a játékot, és ha igen, hogyan, illetve ötleteket kértem tőlük a játék tovább fejlesztésére vonatkozóan. Elvira, HR koordinátorként kiváló rálátással rendelkezik a cégét, illetve a szektort érintő jellemzőkre. Interjúalanyaim véleménye szerint az Edupoly egy érdekes megközelítése a szektor ismeretségének a növelésére. Szerintük rendkívül kreatív és egy nagy pozitívuma, hogy bármilyen változásra képes reagálni a társas általános felépítése miatt. A kisebb és nagyobb cégek is hasznosítani tudnák, viszont Elvira úgy gondolja, hogy a kisebb létszámú cégeknél magáról a cégről is lehetnének benne információk. Ezért a játék továbbfejlesztésére vonatkozó javaslatai között elsősorban az szerepelt, hogy azt érdemes lenne egy-egy cégre „szabni”. Mindez az AGCO-ból kiindulva azt jelentené, hogy a társas egy 
mezőgazdasági témakörre lenne ráhúzva, amelyben a cég termékei jelennek meg. Ezáltal a céget és termékeit is népszerüsíteni tudnák. A cég környezete és hangulata a családi barátságos jellege is megjelenne a táblán és főleg a szerencsekártyák tartalmában. Viszont felhívták a figyelmemet arra is, hogy egy kisebb SSC nem feltétlen költene pénzt egy társasjátékra, ezért inkább a nagyobb multicégeket, illetve a kimondottan a ,játékosítás” elemeire építő nagyvállalatokat célozzam meg, ahol sok a fiatal. Megítélésem szerint ez a játék-fejlesztési feladat akár céges csapatépítés célját is szolgálhatná, kiváló lehetőséget teremthetne arra, hogy a dolgozói és vezetői ötleteket együtt, kombinálva a saját tapasztalataikat és megtörtént eseményeket ültetnék át társas formájába. A csapatokon belül, más csapatokkal és a vezetőséggel is egy szorosabb kapcsolat alakulhat ki a játék kidolgozása során. A kész játéknál a dolgozók büszkén jelenthetik ki, hogy részt vettek benne és ezt az egész cég közremüködése során hozták létre. Emellett a dolgozók önkritikát tudnak gyakorolni. Így a társas hatalmas értéket képvisel majd a dolgozók szemében. Employer branding-ként is felhasználható, mert ez által a dolgozók jobban fognak kötődni a cégükhöz.

A játék hasznosítása sokrétűen képzelhető el. Elvira szerint a nagyobb rendezvényeken, mint például a HVG állas börzén tudnák hasznosítani vagy a hasonló céges eseményeken, mint például a „Board Game Nights”-on, nyílt napokon vagy a különböző Recruitment eseményeken. Én szintén hasonló véleményen vagyok. Azok a cégek, melyek ellátogatnak középiskolákba, népszerüsíteni a céget, illetve a szektort, ugyancsak hasznát vennék az Edupoly személyre szabott változatának. A társas alakítható, a vállalatok, akár a saját példáira építkezve magát és az ottani napokat is bemutathatja vele. Viszont felhívták a figyelmemet az idő kérdésére, az események sokszínüsége és gyorsan történő események és a nagy mennyiségü résztvevő miatt. Egy nyíltnapon, az állásbörzén vagy akár egy csapatépítőn nem lesz annyi idő, hogy egy 3-4 órás társasjátékot végig játszanak az érdeklődők. Ez a mostani rohanó világban nem is kérdéses. Ezért Elvira és csapata szerint célszerü létrehozni egy gyorsított változatát a társasnak. Vagy csak a kártyákat felhasználva egy szerencsekereket létrehozni, amit megpörgetve különböző nyereményekhez juthatnak hozzá. A céges alkalmazási lehetőségeken túlmenően megítélésem szerint számtalan egyéb alkalmazási lehetőség rajzolódik ki. Elképzelhető az Edupoly oktatási segédanyagként például olyan egyetemeken, ahol van SSC képzés, mint például az Edutus Egyetemen vagy a Szegedi Tudomány egyetemen. A társas a tanóra keretein belül is felhasználható, ahol a tömény tananyag mellett játékos tapasztalatokat is szerezhetnek a diákok. Az Egyetemek a nyíltnapjaikon is nyújthatnak az érdeklődőknek érdekes és játékos információt a szektorról és a képzéseiről is. A diákok több egyetem/ föiskola 
nyíltnapját is meg szokták látogatni, mielőtt döntenének, arról, hova mennyjenek továbbtanulni. Ilyenkor az a kérdés, hogy melyik iskola tett rájuk nagy benyomást és mire emlékeznek majd a nyíltnapból. A hagyományos prezentációk nem kötik le az Y és Z generáció tagjai, a tartalmára meg szinte nem is emlékeznek. Azonban, egy szokatlan előadásmód, bemutató vagy játék, egész biztos, hogy maradandó élményt hagy. Egy társasjáték, pont ilyen, figyelemfelkeltő, szórakoztató és még tanulhatnak is belőle. Azonban kivihető az Educatio-ra is, ahol az egyes egyetemek mutatják be magukat és szakirányaikat, ahol szintén kiváló megoldás lehet az SSC specializációt a társas keretein belül népszerüsíteni. Ezen kívül, mindenképp ajánlanám már a gimnáziumokban és az olyan középiskolákban, ahol valamilyen közgazdász ismereteket tanítanak a társas bemutatását, mert célszerü a fiatalokat minél előbb megfogni. Ez azért is fontos, mert sok nyitott pozíció van a szektorban, amit egy érettségivel és folyékony nyelvtudással be tudnak a diákok tölteni, akár diákként, akár fő állásúként.

\section{Összegzés}

Az SSC szektor a magyar gazdaság életében kiemelkedő szerepet játszik, mégis kevesen ismerik ezeket a vállalatokat. Fontos, hogy felhívjuk a figyelmet a szektorra, amely, gamification és employer branding eszközöket használva rengeteg erőfeszítést tesz azért, hogy a szektor dolgozói jól érezzék magukat munkájuk során. A fő célcsoportja a fiatalabb generáció, akik lehetőségeiket nem ismerve külföldre mennének dolgozni, holott a szektor tökéletesen illeszkedik az általuk elképzelt munkahelyhez, trendekhez, fizetéshez. A szektor népszerüsítésének a kérdése sokféle problémára megoldást nyújthat. Épp ezért nagyon fontos annak népszerüsítése.

Az Edupoly játék nagy előnye, mint a fentiekben leírtam, hogy nem csak a gyermekek számára fontos a játék, hanem a felnőtteknek is. Ezzel a játékkal tehát azt szeretném elérni, hogy a leendő alkalmazottak, minél előbb megismerjék az SSC-ket. Ezen játékon keresztül megtapasztalhatják, azt is, hogy milyen tulajdonságokkal rendelkeznek ezek a nagy multinacionális vállalatok, hogy milyen karrierutakat járhatnak be velük, hogy ehhez milyen készségek szükségesek és azt is, hogy milyen lehetőségeket kínál nekik a cég. Ha ezeket a tényezőket minél előbb megismerik, annál hamarabb tudnak a jövőjük kapcsán dönteni. Hamarabb fel tudnak erre készülni, így a cégek is sokat nyernek vele. Egyrész a szektor ismertebb lesz, mint valaha, és emellett olyan alkalmazottak jelentkezését várhatják, akik akár már a gimnázium óta erre készülnek, így hatalmas tudást halmoztak fel. Hisz pontosan tudatában lesznek a szektor minden negatívumával és pozitívumával. A fiatalabb generáció, 
nem hoz elhamarkodott döntéseket, mindemellett szeretnek játszani, ezért ideális egy társasjáték keretein belül a tudatukra hozni ezen információkat a pontosabb döntéshozatal érdekében. Tágabb értelemben véve nemcsak az SSC szektorban érintett cégek, oktatási intézmények, érdekképviseletek, hanem nagyobb célközönség számára is lehetne szórakoztató és egyúttal tanulságos játék. Vagyis az Edupoly véleményem szerint egy önálló, új termékként is piacosítható lenne. E folyamatnak a részletes kidolgozása azonban túlmutat e szakdolgozat keretein és egy újabb elemzés témája lehetne. 


\section{FELHASZNÁLT IRODALOM}

1. Barna Eszter (2017), Munkaerö-megtartás a HR kulcskérdése https://www.hrportal.hu/hr/munkaero-megtartas-a-hr-kulcskerdese-20170111.html

2. Éberfi Zsuzsanna, Engelhadt Fanni, Kutor Norbert, A "Gamification" alkalmazásának lehetöségei.

http://www.elitmed.hu/ilam/gondolat/a_gamification_alkalmazasanak_lehetosegei_12 $\underline{197 /}$

3. Hrpwr.hu, (2019), 10 kulcsfontosságú HR-trend, ami diktálja az iramot 2019-ben. http://hrpwr.hu/megtartas/cikk/10_kulcsfontossagu_hr_trend_ami_diktalja_az_iramot _2019_ben

4. HVg.hu (2018), a munkavállalói élmény, kutatás szerint a cégek rájöttek, érdemes akkor is jóban maradni a munkavállalóval, ha elválnak útjaik.

https://hvg.hu/enesacegem/20180216_Nem_a_berezes_a_legnagyobb_HRproblema Magyarorszagon

5. Németh, T. (2015), English Knight: Gamifying the EFL Classroom English Knight: Gamifying the EFL Classroom (Unpublished master's thesis). Pázmány Péter Katolikus Egyetem Bölcsészet- és Társadalomtudományi Kar https://ludus.hu/gamification/

6. Profession.hu, minden az employer brendingről és a megvalósítás konkrét folyamata. https://www.profession.hu/docs/profession_employer_branding.pdf, 7-18o.

7. Profession (2017), a legkreatívabb toborzási és kiválasztási stratégiák. https://www.profession.hu/blog/a-legkreativabb-toborzas-modszerei/

8. Velenczei Róbert, (2014), Gamification, vagyis az ismeretátadás játékosítása. https://www.controllingportal.hu/gamification_vagyis_az_ismeretatadas/

9. Virág Narancsik, (2019), Az Y és a Z generációs fiatalok megtartása a gamification eszközeivel. https://sscheroes.com/hu/blog/az_Y_\%C3\%A9s_a_Z_generacios_fiatalok_megtartasa _a_gamification_eszkozeivel 